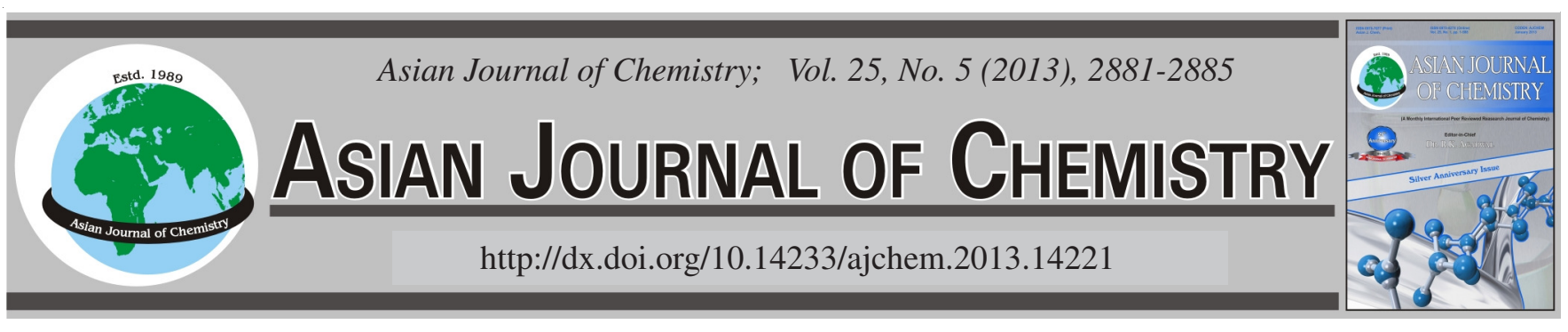

\title{
Analysis of Soil from the Black Sea Region of Northern Turkey Using Energy Dispersive X-Ray Fluorescence Spectrometry
}

\author{
R. EkINCI ${ }^{1}$, B. Dogan ${ }^{2}$, N. EkINCI ${ }^{2, *}$, B. BILYEU ${ }^{3}$ and R. Jones ${ }^{4}$
}

${ }^{1}$ Department of Food Engineering, Engineering Faculty, Pamukkale University, Denizli, Turkey

${ }^{2}$ Department of Physics, Faculty of Science, Ataturk University, 25240, Erzurum, Turkey

${ }^{3}$ Department of Chemistry, Xavier University of Louisiana, New Orleans, LA 70125, USA

${ }^{4}$ Department of Chemistry and Physics, Texas Woman's University, Denton, TX 76204, USA

*Corresponding author: Fax: +90 442 2360948; Tel: +90 442 2314165; E-mail: nekinci@atauni.edu.tr; neslihanekinci@yahoo.com

This study, examines trace element analysis of eighteen soil samples taken from the provinces of Trabzon and Giresun. The concentrations of trace elements were determined using energy dispersive X-ray fluorescence. The physical basis of the analytical method used, experimental set up and the sample preparation are described. X-ray spectra were collected using a Si(Li) detector with a Camberra DSA-1000 desktop spectrum analyzer and $\mathrm{Am}^{241}$ and $\mathrm{Fe}^{55}$ annular radioactive sources. The energy resolution of the spectrometer is $160 \mathrm{eV}$ at $5.9 \mathrm{keV}$.

Key Words: Soils, Energy dispersive X-ray fluorescence, Trace elements.

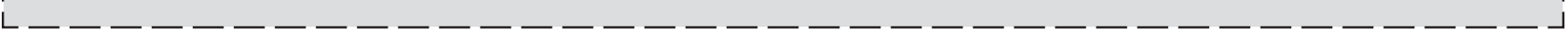

\section{INTRODUCTION}

The ever-increasing pollution of the environment has been one of the greatest concerns for science and the general public in the last 50 years. The rapid industrialization of agriculture, expansion of the chemical industry and the need to generate cheap forms of energy has caused the continuous release of man-made chemicals into natural ecosystems. Consequently, the atmosphere, bodies of water and many soil environments have become polluted by a large variety of toxic compounds. Many of these compounds at high concentrations or following prolonged exposure have the potential to produce adverse effects in humans and other organisms. These include the danger of acute toxicity, mutagenesis (genetic changes), carcinogenesis and teratogenesis (birth defects) for humans and other organisms. Some of these toxic compounds are resistant to physical, chemical or biological degradation and thus may stay resident in the environment for long periods of time increasing the effects of bio accumulation and bio magnification.

Historically, many researchers have experimented and developed various analytical techniques to analyze rare earth elements. The rare earth elements, particle size distribution and mineralogical composition in the soils on the flood plains developed by the three major rivers of the Brahmaputra, Meghna and Ganges in Bangladesh were analyzed ${ }^{1}$. The concentrations of 57 elements in 514 soils samples collected from 78 sampling sites throughout Japan were determined and the elemental composition of Japanese soils were discussed, with special references to differences among soil groups and the influence of agricultural activity ${ }^{2}$. The trace element distributions of polluted soils in Hungary were determined by $\mathrm{X}$-ray methods ${ }^{3}$. The background concentrations of 13 soil trace elements and their relationships to parent materials and vegetation in Xizang (Tibet), China were reported ${ }^{4}$. The chemical composition of 73 surface soil samples collected at the city of Antalya was analyzed for major, minor and trace elements to assess distribution of soil pollution, due to deposition of pollution-derived particles from atmosphere ${ }^{5}$. Furthermore, multi-element analysis of soil samples by energy dispersive X-ray fluorescence has been done to find the profile of agricultural soil ${ }^{6}$. An experimental determination of the source profiles of soil in Hong Kong was also done ${ }^{7}$. A method was developed for the analysis of the trace elements of soils using X-ray fluorescence spectrometry. The method was successfully applied to the determination of the distribution of elements ${ }^{8}$.

The main objective of the present research is to determine the level of soil pollution in the eastern Black Sea region of northern Turkey and to use to energy dispersive X-ray fluorescence to assess the elemental distribution in this region.

The eastern Black Sea region was chosen because of its high agriculture productivity. It has a moderate climate with 
high rainfall. This area averages $2500 \mathrm{~mm}$ annually which is the highest precipitation in the country. This gives the advantage of analyzing the rainfall throughout all seasons. The mild, damp climate of the eastern black sea region makes commercial farming profitable year-round. This geography also has a diverse ecology including woodlands with hornbeam, chestnut, spruce and alder trees and a rich shrub layer of rhododendron, laurel, holly, myrtle, hazel- and walnut. Commercially, farmers grow a variety of crops including corn, flax, fruit trees (hazelnuts, cherries, plums, etc.), tobacco and tea.

Silicon is the second most abundant element, after oxygen, in the Earth's crust (27\%) and occurs mainly as $\mathrm{SiO}_{2}$, in considerable amounts in nature. Silicon is commercially produced by heating $\mathrm{SiO}_{2}$ and carbon in an electric furnace using carbon electrodes. Due to its versatile properties, silicon is used in many different sectors of industry. It is used in the electronics to produce transistors, computer chips and solar cells, because it has good semiconductor properties. It has commonly used high temperatures devices, because of its high melting point. Silicon is useful refractory material for high temperature processes and as silicate, is used in the production of bricks, pottery, enamel, etc. Silica is the main ingredient of glass and silicon monoxide and widely used as a protective coating. It is also used as an alloying element in the metallurgical industry, especially in the steel and aluminum industries.

Silicon is a common mineral constituent of plants, however, it is not defined to be essential. Its amount varies greatly, mainly upon plant species.

Although iron is the fourth most abundant element in the lithosphere (about $5 \%$ ) and isn't considered a trace element. It is an essential micronutrient and indicator of soil quality. Iron makes up about 3-4 \% of the elemental composition of most soils and usually occurs as ferromagnesium silicates. Iron deficiency is considered the most widespread malnutrition problems in both plants and animals worldwide ${ }^{9}$.

Calcium is the fifth most abundant element in the earth's crust (almost $4 \%$ ) and is the most abundant metal (by mass) in the human body. Calcium is a component of several primary and secondary minerals in the soil. It stimulates root and leaf development, forms cell wall components, aids in the reduction of nitrates, activates enzyme activities and neutralizes organic acids. Calcium reduces soil acidity, which in turn lowers solubility and toxicity of manganese, copper and aluminum. Calcium improves root growth, microbial activity and stimulates nutrient uptake. Calcium also acts as a neutralizing agent to control soil $\mathrm{pH}$. Most crops prefer a near-neutral $\mathrm{pH}$ level, where the base saturation of calcium falls between $65 \%$ and $75 \%$. When $\mathrm{pH}$ levels are extremely low, a calcium deficiency may result. Calcium deficiencies also happen when $\mathrm{pH}$ is very low and magnesium and/or potassium levels cause symptoms similar to those of amide herbicide injury, where newly emerging corn leaves fail to unfold because leaf tips stick together. Affected plants may also have a slight yellow green tint and may be severely stunted. However, the side effects of low calcium will usually affect corn growth adversely before levels drop low enough for leaf symptoms to develop. Calcium can also limit yields if the concentration is too high. The best way to both avoid and treat a calcium deficiency is to maintain an adequate $\mathrm{pH}$ level, which may be done with the application of lime.
Potassium is the seventh most abundant element in the Earth's crust (almost $3 \%$ ) and is an essential element for life. All plants require fairly high concentrations of potassium for normal growth and development, so it is one of the primary elements used to classify fertilizers and to indicate soil quality. Potassium is responsible for chlorophyll formation, plays an important part in the strength of cells and encourages flower and fruit formation. Thus potassium can enhance the ability of the plant to resist diseases, insect attacks and cold conditions. Potassium performs a vital role in the formation of starch as well the production and translocation of sugars in the plant. Plants that exhibit symptoms of potassium deficiency will have weak stems. Other symptoms of potassium deficiency include older leaves that are floppy with yellow tips and brown margins. Even high potassium levels cannot overcome the effects of a severe drought. Under extremely dry growing conditions, plants cannot extract enough potassium for optimal growth and yield, even if potassium levels are adequate.

Titanium is ninth most common element in the lithosphere show the strong lithophilic characteristic and is a common constituent of rocks, in the range of 0.03-1.4\%. It is average abundance in the Earth's crust is given as 0.4-0.6\%. Titanium contents in surface soils range from 0.02 to $2.4 \%$. Calculated mean for worldwide soil is $0.33 \%$. Since Ti minerals are very resistant to weathering they are used as an index for soil genesis ${ }^{10}$.

Strontium is the $16^{\text {th }}$ most abundant element in the Earth's crust with a concentration range of $260-730 \mathrm{mg} \mathrm{kg}^{-1}$. It is commonly found as the sulfate or the carbonate mineral and tends to concentrate in mafic igneous rocks and in carbonate sediments. The average strontium content of most soils is around $250 \mathrm{mg} \mathrm{kg}^{-1}$. In terms of geological and biochemical characteristics, $\mathrm{Sr}$ is very similar to $\mathrm{Ca}$. Due to the similarity, $\mathrm{Sr}$ follows the same biological uptake mechanism as $\mathrm{Ca}$ and can substitute for $\mathrm{Ca}$ in some biological processes like bone calcification. However, it appears to be neither necessary nor toxic. Strontium occurs in all mammalian tissues in the range from 0.09 to $0.24 \mathrm{mg} \mathrm{kg}^{-1}$. High levels of $\mathrm{Sr}$ are associated with coal combustion and sulfur mining/processing.

Zirconium is found at a concentration of $100-200 \mathrm{mg}$ $\mathrm{kg}^{-1}$ in the earth's crust (much lower in ultra mafic rocks and calcareous sediments) and much smaller concentrations in seawater, Zirconium is commonly found as its silicate, Zircon $\left(\mathrm{ZrSiO}_{4}\right)$, but is industrial processed into both metal and oxide forms. Zirconia $\left(\mathrm{ZrO}_{2}\right)$ is particularly valued for its high heat and corrosion resistance. Although $\mathrm{Zr}$ has no known biological role and is essentially nontoxic, it is found in trace amounts in some plants and animals. Aquatic plants take up soluble zirconium compounds, but it is rare to find in land plants. When it is found in land plants, the source is usually industrial particulates.

Rubidium occurs in the upper continental crust at concentrations of $90-310 \mathrm{mg} \mathrm{kg}^{-1}$ and in soils at $100-120 \mathrm{mg} \mathrm{kg}^{-1}$. Geologically $\mathrm{Rb}$ behaves similarly to other group I metals, but its large ionic radius affects its crystallization. $\mathrm{Rb}$ doesn't appear to be an essential element, but is taken up by plants and animals in the same way as $\mathrm{K}$.

Niobium (also called columbium) is relatively common in the earth's crust ( $33^{\text {rd }}$ most common element) at an average 
content of $26 \mathrm{mg} \mathrm{kg}^{-1}$. The concentration of $\mathrm{Nb}$ is higher in acid igneous rocks and in argillaceous sediments. In the nature $\mathrm{Nb}$ and $\mathrm{Ta}$ occur together because of their chemical similarities. This metal is used mainly for carbon and stainless steel alloys. It is also applied for welding and nuclear industry tools. Niobium containing alloys are resistant to strength and to cryologic factors, therefore are widely used in pipeline constructions and in aerial transportation industries. Niobium is not biologically active and is classified as a hypoallergenic material, so is used in jewelry. The mean concentration of $\mathrm{Nb}$ in soft tissues of humans is around $27 \mu \mathrm{g} \mathrm{kg}^{-1}$, being the lowest in kidney $10 \mu \mathrm{g} \mathrm{kg}^{-1}$ and the highest in lymph $60 \mu \mathrm{g} \mathrm{kg}^{-1}$.

\section{EXPERIMENTAL}

The elemental concentrations in soil samples were determined using the equation:

$$
w_{i}=\frac{N_{i j}}{I_{0} G \varepsilon_{i j} \sigma_{i j} \beta_{i j} m}
$$

where, $\mathrm{w}_{\mathrm{i}}$ is the concentration of the element present in the sample, $\mathrm{N}_{\mathrm{ij}}$ is the net counts/unit time for the $\mathrm{I}^{\text {th }}$ group of $\mathrm{X}$-rays of the $\mathrm{j}^{\text {th }}$ element, $\mathrm{I}_{0}$ is the intensity of incident photon, $\mathrm{G}$ is a geometric factor, $\varepsilon_{\mathrm{ij}}$ is the efficiency of the detector for the $\mathrm{I}^{\text {th }}$ group of $\mathrm{X}$-rays of the $\mathrm{j}^{\text {th }}$ element, $\mathrm{m}$ is the sample mass in $\mathrm{g} \mathrm{cm}^{-2}, \beta_{\mathrm{ij}}$ is the self-absorption correction factor of the target material, which the target material which accounts for the absorption by the target of the incident photons and emitted characteristic X-rays of the $\mathrm{I}^{\text {th }}$ peak of the $\mathrm{j}^{\text {th }}$ element. $\sigma_{\mathrm{ij}}$ is the $\mathrm{X}$-ray fluorescence cross section of the $\mathrm{I}^{\mathrm{th}}$ group of X-rays of the $\mathrm{j}^{\text {th }}$ element. For example; $\mathrm{X}$-ray fluorescence cross sections for $\mathrm{K} \alpha \mathrm{X}$-ray yields following relationship:

$$
\sigma_{\mathrm{K} \alpha}=\sigma_{\mathrm{K}} \omega_{\mathrm{K}} \mathrm{f}_{\mathrm{K} \alpha}
$$

where, $\alpha_{K \alpha}$ is the $\mathrm{K}$ shell photoionization cross section ${ }^{11}, \omega_{\mathrm{K}}$ is the $\mathrm{K}$ shell fluorescence yield ${ }^{12}$ and $f_{\mathrm{K} \alpha}$ is the fraction of $\mathrm{K} \alpha$ $\mathrm{X}$-rays in the $\mathrm{K} \mathrm{X}$-rays ${ }^{13}$.

The factor $\mathrm{I}_{0} \mathrm{G} \varepsilon$ in equation (1) has been evaluated by running, separately, the K X-ray spectra of a number of spectroscopically pure powders of $\mathrm{Fe}, \mathrm{Zn}, \mathrm{Br}, \mathrm{Zr}$, Mo, In, Sn, Cs, Nd, $\mathrm{Gd}$ and Er of known concentrations for an annular $\mathrm{Am}^{241}$ source and $\mathrm{K}, \mathrm{Ca}, \mathrm{Ti}, \mathrm{V}$ and $\mathrm{Cr}$ of known concentrations for an annular $\mathrm{Fe}^{55}$ source. The graphic of $\mathrm{I}_{0} \mathrm{G} \varepsilon$ for a $\mathrm{Fe}^{55}$ annular radioactive source is shown in Fig. 1.

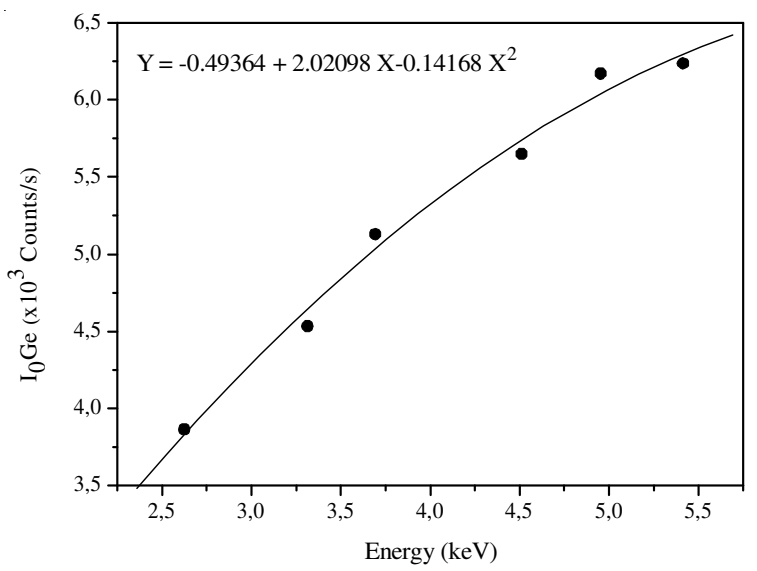

Fig. 1. Graphic of $\mathrm{I}_{0} \mathrm{G} \varepsilon$ for $\mathrm{Fe}^{55}$ annular radioactive source
The test sites are all under cultivation and are indicated in Fig. 2. Three soil samples were taken from each of the six provinces of Trabzon and Giresun. The samples were collected at a depth of $30 \mathrm{~cm}$ from different fields. The analysis of elements present in the soils was carried out by EDXRF. The experimental system is shown in Fig. $3^{14}$. For the present study, $5.9 \mathrm{keV}$ photons emitted from ${ }^{55} \mathrm{Fe}$ and $59.5 \mathrm{keV}$ photons emitted from ${ }^{241} \mathrm{Am}$ radioactive sources were used to excite the characteristic X-rays of the elements present in the samples. The main advantage of radioisotope excitation over X-ray tube excitation is in the monoenergetic nature of the radioisotopeemitted X-rays, but it is also inexpensive and commercially available. For the other types of excitation modes, e.g. an $\mathrm{X}$-ray tube, the spectral distribution relationship between scattered and background radiation intensities is more complex owing to the bremsstrahlung continuum. X-ray spectra were collected using a $\mathrm{Si}(\mathrm{Li})$ detector with a preamplifier, spectroscopy amplifier, HV bias supply and a multichannel analyzer which includes an analog to digital converter (ADC). The energy resolution of the detector was $160 \mathrm{eV}$ (full width half maximum) at $5.9 \mathrm{keV}$. The spectrum acquisition times for soils were $12 \mathrm{~h}$ for the ${ }^{241} \mathrm{Am}$ radioactive source and $24 \mathrm{~h}$ for the ${ }^{55} \mathrm{Fe}$.

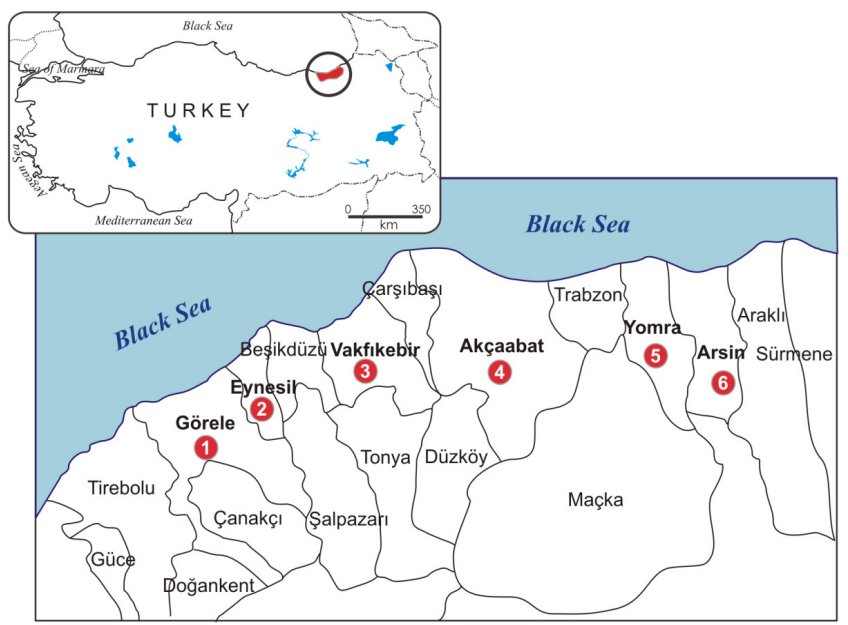

Fig. 2. Geographic areas (cultivation areas) included into the study

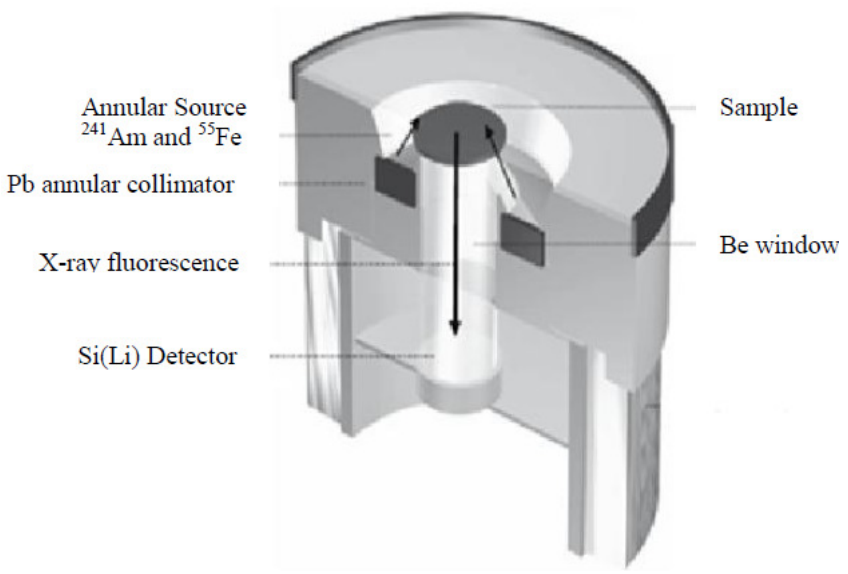

Fig. 3. Experimental system

The soil samples were oven-dried at $300^{\circ} \mathrm{C}$ for $4 \mathrm{~h}$. After drying, the materials were ground and sieved to a mesh size 
of $100 \mathrm{~mm}$. A 10 ton hydraulic press was used to compress the sample powders into thin pellets of $12 \mathrm{~mm}$ diameter. Mass thickness of soil samples was chosen as $0.2-0.3 \mathrm{~g} / \mathrm{cm}^{2}$ to reduce the matrix effect. The advantage of making these pellets is that interelement enhancement effects in the sample are minimized. The effects of the matrix composition on the measured analyte-line intensity are known as matrix-, inter-element-, self-absorption- and absorption-enhancement effects. Whatever absorption-enhancement effects a specified analytematrix system may be subject to, they increase with increasing thickness, decrease with decreasing thickness and essentially disappear in thin samples ${ }^{15}$.

\section{RESULTS AND DISCUSSION}

The mean concentrations and relative standard deviations (RSD) of the element observed in 18 soil samples for ${ }^{241} \mathrm{Am}$ and ${ }^{55} \mathrm{Fe}$ annular radioactive sources are shown Tables 1 and 2 . The representative spectra of Görele 1 for the ${ }^{241}$ Am radioactive source are shown in Figs. 4 and 5 and the representative spectrum of Görele 1 for the ${ }^{55} \mathrm{Fe}$ annular radioactive source is shown in Fig. 6. Since the potassium K $\alpha$ line overlaps with the $\mathrm{K} \beta$ line of argon from air, the potassium concentration was calculated by subtracting the signal from a blank air sample. The concentrations of $\mathrm{Si}, \mathrm{K}, \mathrm{Ca}$ and Ti from the ${ }^{55} \mathrm{Fe}$ data and $\mathrm{Fe}, \mathrm{Rb}, \mathrm{Sr}, \mathrm{Zr}$ and $\mathrm{Nb}$ from the ${ }^{241} \mathrm{Am}$ data determined by EDXRF spectra are listed in Tables 1 and 2 . The relative standard deviation in all of the measurements is estimated to be less than $10 \%$.

(Görele-1)

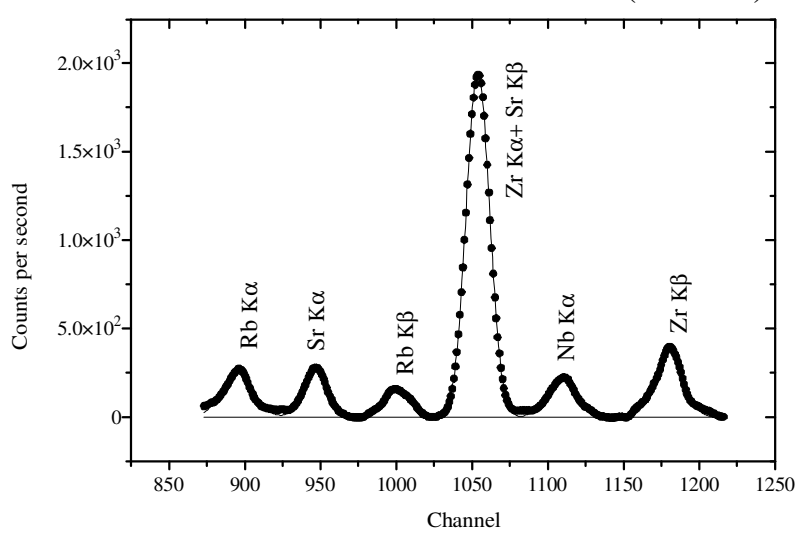

Fig. 4. Representative spectra of Görele 1 for ${ }^{241} \mathrm{Am}$ annular radioactive sources

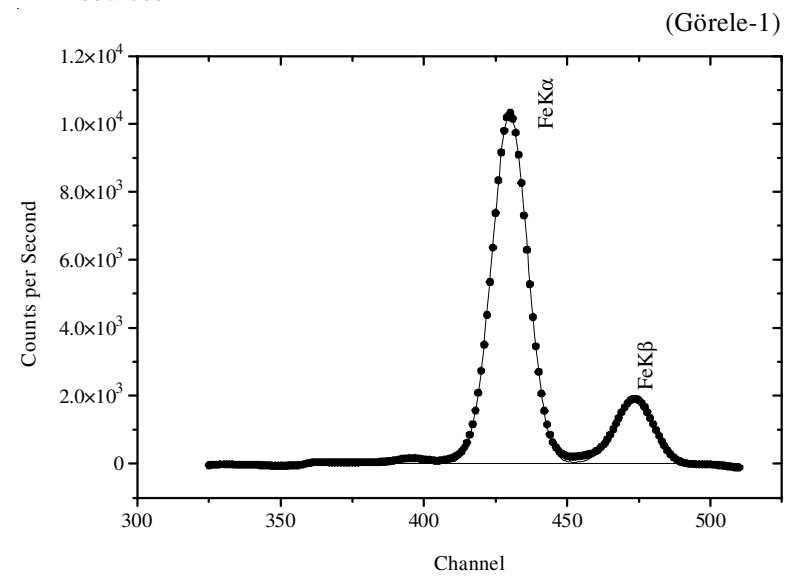

Fig. 5. Representative spectra of Görele 1 for ${ }^{241} \mathrm{Am}$ annular radioactive sources
TABLE-1

MEAN CONCENTRATIONS AND RELATIVE STANDARD DEVIATIONS (RSD) OF THE ELEMENTS OBSERVED IN EIGHTEEN SOIL SAMPLES FOR ${ }^{55} \mathrm{Fe}$ ANNULAR RADIOACTIVE SOURCE

\begin{tabular}{|c|c|c|c|c|}
\hline \multirow[b]{2}{*}{ Samples } & \multicolumn{4}{|c|}{ MEAN CONCENTRATION (\%) \pm RSD } \\
\hline & $\mathrm{Ca}$ & $\mathrm{K}$ & $\mathrm{Si}$ & $\mathrm{Ti}$ \\
\hline Görele-1 & $\begin{array}{c}4.49 \pm \\
0.29\end{array}$ & $\begin{array}{c}4.71 \pm \\
0.33\end{array}$ & $\begin{array}{c}28.42 \pm \\
2.26\end{array}$ & $\begin{array}{c}0.00362 \pm \\
0.00027\end{array}$ \\
\hline Görele-2 & $\begin{array}{c}2.45 \pm \\
0.13\end{array}$ & $\begin{array}{c}2.62 \pm \\
0.19\end{array}$ & $\begin{array}{c}32.05 \pm \\
2.54\end{array}$ & $\begin{array}{c}0.00242 \pm \\
0.00008\end{array}$ \\
\hline Görele-3 & $\begin{array}{c}5.61 \pm \\
0.32\end{array}$ & $\begin{array}{c}2.74 \pm \\
0.16\end{array}$ & $\begin{array}{c}33.40 \pm \\
1.96\end{array}$ & $\begin{array}{c}0.00396 \pm \\
0.00022\end{array}$ \\
\hline Eynesil-1 & $\begin{array}{c}3.88 \pm \\
0.17\end{array}$ & $\begin{array}{c}6.12 \pm \\
0.32\end{array}$ & $\begin{array}{c}26.14 \pm \\
1.05\end{array}$ & - \\
\hline Eynesil-2 & $\begin{array}{c}6.41 \pm \\
0.31\end{array}$ & $\begin{array}{c}3.26 \pm \\
0.17\end{array}$ & $\begin{array}{c}24.56 \pm \\
1.32\end{array}$ & - \\
\hline Eynesil-3 & $\begin{array}{c}6.67 \pm \\
0.28\end{array}$ & $\begin{array}{c}2.63 \pm \\
0.21\end{array}$ & $\begin{array}{c}27.7 \pm \\
1.88\end{array}$ & - \\
\hline Vakf:kebir-1 & $\begin{array}{c}4.59 \pm \\
0.21\end{array}$ & $\begin{array}{c}6.63 \pm \\
0.28\end{array}$ & $\begin{array}{c}28.16 \pm \\
2.14\end{array}$ & $\begin{array}{c}0.0327 \pm \\
0.0018\end{array}$ \\
\hline Vakf'kebir-2 & $\begin{array}{c}4.62 \pm \\
0.24\end{array}$ & $\begin{array}{c}5.81 \pm \\
0.26\end{array}$ & $\begin{array}{c}35.10 \pm \\
2.64\end{array}$ & $\begin{array}{c}0.0287 \pm \\
0.0014\end{array}$ \\
\hline Vakf:kebir-3 & $\begin{array}{c}4.28 \pm \\
0.22\end{array}$ & $\begin{array}{c}5.66 \pm \\
0.32\end{array}$ & $\begin{array}{c}25.76 \pm \\
1.46\end{array}$ & $\begin{array}{c}0.0362 \pm \\
0.0021\end{array}$ \\
\hline Akçaabat-1 & $\begin{array}{c}6.15 \pm \\
0.30\end{array}$ & $\begin{array}{l}3.12 \pm \\
0.15\end{array}$ & $\begin{array}{c}27.62 \pm \\
1.68\end{array}$ & $\begin{array}{c}0.0391 \pm \\
0.0036\end{array}$ \\
\hline Akçaabat-2 & $\begin{array}{c}6.73 \pm \\
0.43\end{array}$ & $\begin{array}{c}5.61 \pm \\
0.36\end{array}$ & $\begin{array}{c}34.27 \pm \\
3.32\end{array}$ & $\begin{array}{c}0.0421 \pm \\
0.0045\end{array}$ \\
\hline Akçaabat-3 & $\begin{array}{c}4.67 \pm \\
0.22\end{array}$ & $\begin{array}{c}6.96 \pm \\
0.42\end{array}$ & $\begin{array}{c}34.62 \pm \\
2.98\end{array}$ & $\begin{array}{c}0.0437 \pm \\
0.0017\end{array}$ \\
\hline Yumra-1 & $\begin{array}{c}3.77 \pm \\
0.22\end{array}$ & $\begin{array}{c}5.31 \pm \\
0.49\end{array}$ & $\begin{array}{c}27.72 \pm \\
2.14\end{array}$ & - \\
\hline Yumra-2 & $\begin{array}{c}4.97 \pm \\
0.36\end{array}$ & $\begin{array}{c}6.56 \pm \\
0.33\end{array}$ & $\begin{array}{c}21.92 \pm \\
1.91\end{array}$ & - \\
\hline Yumra-3 & $\begin{array}{c}4.69 \pm \\
0.29\end{array}$ & $\begin{array}{c}4.49 \pm \\
0.22\end{array}$ & $\begin{array}{c}28.24 \pm \\
1.78\end{array}$ & - \\
\hline Arsin-1 & $\begin{array}{c}4.35 \pm \\
0.33\end{array}$ & $\begin{array}{c}3.88 \pm \\
0.16\end{array}$ & $\begin{array}{c}31.68 \pm \\
2.62\end{array}$ & - \\
\hline Arsin-2 & $\begin{array}{c}3.84 \pm \\
0.22\end{array}$ & $\begin{array}{c}6.83 \pm \\
0.39\end{array}$ & $\begin{array}{c}28.73 \pm \\
1.96\end{array}$ & - \\
\hline Arsin-3 & $\begin{array}{c}5.42 \pm \\
0.39 \\
\end{array}$ & $\begin{array}{c}4.11 \pm \\
0.26\end{array}$ & $\begin{array}{c}36.91 \pm \\
2.90\end{array}$ & - \\
\hline
\end{tabular}

The concentrations of strontium, zirconium and rubidium in the investigated soils are higher than expected. Concentration ranges of strontium in the samples are $0.0188-0.0693 \%$. Concentration ranges of zirconium in the samples are 0.00142-0.00821 $\%$. Also, concentration ranges of rubidium in the samples are 0.00108-0.00691\%.

Soil is the main source of trace elements for plants both as micronutrients and as pollutants. Soils contain trace elements of various origins: 1) lithogenic- inherited from the lithosphere ( parent material) 2) pedogenic 3) anthropogenic. Soils around the world are under stress and are being mined for their nutrients. Some of these stresses include the application of mineral fertilization, pesticides, waste disposal and industrial pollution. These activities both human and natural, result in altering the chemical and physical aspects of the soil, which in turn alter the trace elements. The interruption $f$ trace mineral up take by crops has serious implications for the environment and human health.

In conclusion, it is necessary to analyze $\mathrm{Ca}, \mathrm{K}, \mathrm{Si}, \mathrm{Ti}, \mathrm{Fe}$, $\mathrm{Zr}, \mathrm{Sr}, \mathrm{Rb}$ and $\mathrm{Nb}$ elements that occur in the soil to assess their abundance and distribution. Observing changes in elemental 
TABLE-2

MEAN CONCENTRATIONS AND RELATIVE STANDARD DEVIATIONS (RSD) OF THE ELEMENTS OBSERVED IN EIGHTEEN SOIL SAMPLES FOR ${ }^{241}$ Am ANNULAR RADIOACTIVE SOURCE

\begin{tabular}{|c|c|c|c|c|c|}
\hline \multirow[b]{2}{*}{ Samples } & \multicolumn{5}{|c|}{ MEAN CONCENTRATION (\%) \pm RSD } \\
\hline & $\mathrm{Fe}$ & $\mathrm{Zr}$ & $\mathrm{Sr}$ & $\mathrm{Rb}$ & $\mathrm{Nb}$ \\
\hline Görele-1 & $5.61 \pm 0.46$ & $0.00610 \pm 0.00039$ & $0.0377 \pm 0.0022$ & $0.00610 \pm 0.00039$ & $0.00127 \pm 0.00009$ \\
\hline Görele-2 & $6.82 \pm 0.51$ & $0.00344 \pm 0.00026$ & $0.0197 \pm 0.0016$ & $0.00344 \pm 0.00026$ & $0.00107 \pm 0.0001$ \\
\hline Görele-3 & $3.31 \pm 0.19$ & $0.00197 \pm 0.00012$ & $0.0469 \pm 0.0029$ & $0.00197 \pm 0.00012$ & $0.00147 \pm 0.00008$ \\
\hline Eynesil-1 & $3.66 \pm 0.16$ & $0.00487 \pm 0.00028$ & $0.0235 \pm 0.0013$ & $0.00487 \pm 0.00028$ & $0.00196 \pm 0.00012$ \\
\hline Eynesil-2 & $2.57 \pm 0.13$ & $0.00227 \pm 0.00021$ & $0.0661 \pm 0.0032$ & $0.00227 \pm 0.00021$ & $0.00261 \pm 0.00014$ \\
\hline Eynesil-3 & $3.26 \pm 0.32$ & $0.00178 \pm 0.00011$ & $0.0188 \pm 0.0014$ & $0.00108 \pm 0.00011$ & $0.00266 \pm 0.00016$ \\
\hline Vakf?kebir-1 & $5.78 \pm 0.46$ & $0.00254 \pm 0.00017$ & $0.0541 \pm 0.0031$ & $0.00254 \pm 0.00017$ & $0.00362 \pm 0.00027$ \\
\hline Vakf?kebir-2 & $3.83 \pm 0.15$ & $0.00691 \pm 0.00037$ & $0.0597 \pm 0.0028$ & $0.00691 \pm 0.00037$ & $0.00236 \pm 0.00019$ \\
\hline Vakf?kebir-3 & $4.11 \pm 0.26$ & $0.00362 \pm 0.00027$ & $0.0395 \pm 0.0019$ & $0.00362 \pm 0.00027$ & $0.00108 \pm 0.00009$ \\
\hline Akçaabat-1 & $2.72 \pm 0.13$ & $0.00142 \pm 0.00008$ & $0.0682 \pm 0.0036$ & $0.00142 \pm 0.00008$ & $0.00138 \pm 0.00005$ \\
\hline Akçaabat-2 & $2.66 \pm 0.16$ & $0.00296 \pm 0.00022$ & $0.0559 \pm 0.0021$ & $0.00296 \pm 0.00022$ & $0.00116 \pm 0.00007$ \\
\hline Akçaabat-3 & $6.32 \pm 0.28$ & $0.00821 \pm 0.00045$ & $0.0472 \pm 0.0024$ & $0.00691 \pm 0.00045$ & $0.00395 \pm 0.00019$ \\
\hline Yumra-1 & $3.26 \pm 0.17$ & $0.00337 \pm 0.00017$ & $0.0448 \pm 0.0022$ & $0.00337 \pm 0.00017$ & $0.00208 \pm 0.00011$ \\
\hline Yumra-2 & $2.63 \pm 0.21$ & $0.00594 \pm 0.00021$ & $0.0635 \pm 0.0033$ & $0.00590 \pm 0.00021$ & $0.00178 \pm 0.00008$ \\
\hline Arsin-1 & $4.90 \pm 0.27$ & $0.00297 \pm 0.00018$ & $0.0467 \pm 0.0022$ & $0.00297 \pm 0.00018$ & $0.00158 \pm 0.00007$ \\
\hline Arsin-2 & $5.66 \pm 0.32$ & $0.00172 \pm 0.00011$ & $0.0527 \pm 0.0029$ & $0.00282 \pm 0.00015$ & $0.00186 \pm 0.00007$ \\
\hline Arsin-3 & $5.12 \pm 0.38$ & $0.00331 \pm 0.00036$ & $0.0324 \pm 0.0018$ & $0.00231 \pm 0.00019$ & $0.00235 \pm 0.00013$ \\
\hline
\end{tabular}

analysis of soils can help the scientist and farmer to select better methods to ensure the balance and proper transmission of essential elements from soil to plant to consumer. This not only increases agricultural production but has positive health benefits to the consumer. Understanding the ecology of the soil, via its chemistry, is the first step in stabilizing the ecology of the whole biome and sustaining the productivity of the land. In this study, EDXRF technique has proven to be quite adequate for the analysis of soils. The EDXRF technique is fast, reliable and non-destructive and can be used on a routine basis.

\section{REFERENCES}

1. K. Egashira, K. Aramaki, M. Yoshimasa, A. Takeda and S. Yamasaki, Geoderma, 120, 7 (2004).

2. A. Takeda, K. Kimura and S. Yamasaki, Geoderma, 119, 291 (2004).

3. Z. Hartyani, E. David, S. Szabo, V. Szilagyi, T. Horvath, A. Hargitai Toth, Microchem. J., 67, 195 (2000).
4. X.P. Zhang, W. Deng and X.M. Yang, J. Asian Earth Sci., 21, 167 (2002).

5. N. Guvenc, O. Alagha and G. Tuncel, Environ. Int., 29, 631 (2003).

6. V. Singh, H.M. Agrawal, G.C. Joshi, M. Sudershan and A.K. Sinha, Appl. Radiat. Isotop., 69, 969 (2011).

7. K.N. Yu, Z.L.L. Yeung, L.Y.L. Lee, M.J. Stokes and R.C.W. Kwok, Appl. Radiat. Isotop., 57, 279 (2002).

8. T. Horvath, V. Szilagyi and Z. Hartyani, Microchem. J., 67, 53 (2000).

9. P.S. Hooda, Trace Element in Soils, 9, 188 (2010).

10. A. Kabata-Pendias and B.A. Mukherjee, Trace elements from Soil to Human, New York; II-14, II-8, II-5, II-4, II-1, II-2.

11. J.H. Scofield, Lawrence Livermore Nat. Lab. Report No. UCRL 51326 (1973).

12. J.J. Krause, Phys. Chem. Ref. Data, 8, 307 (1979).

13. J.H. Scofield, Atom Data Tbls., 14, 229 (1974).

14. N. Aylikci, E. Tirasoglu, I.H. Karahan, V. Aylikci, E. Cengiz and G. Apaydin, Chem. Phys. Lett., 484, 368 (2010).

15. E.P. Bertin, Principles and Practice of X-Ray Spectrometric Analysis, Plenum Press, New York, Vol. 12, p. 502 (1970). 